\title{
A COMPARATIVE REVIEW OF CARING THINKING AND ITS IMPLICATIONS ON TEACHING AND LEARNING
}

\author{
Anis Shaari \& ${ }^{\mathbf{1}}$ Aswati Hamzah \\ School of Educational Studies \\ Universiti Sains Malaysia, Malaysia

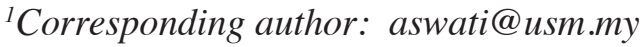

\begin{abstract}
Purpose - This paper undertakes a comparative review of the concept of 'Caring Thinking' from the perspectives of specific scholars (with different cultural voices) in the field of Educational Psychology. Specifically, it focuses on the area of Thinking and Cognition.

Methodology - The review scrutinised the concept of caring thinking in Matthew Lipman's (2003) Thinking Model as well as Mohd Daud Hamzah and Abdul Kadir Arifin's (2001) Islamic Cognitive Processes Model (ICPM). Employing a cross-cultural comparative review, the analysis concentrated on the commonalities shared and the differences between the two schools of thought. The aspects of comparison included cognition principles, caring thinking inventory, thinking direction, human characterisation and role of beings.

Findings - This review suggests that the scholars propagate and share comparable nuances on the underlying characteristics of human cognition in order to facilitate the formation of the caring thinking concept. However, the interplay of human inner drive which incorporates values is deliberated in different cultural voices. While Lipman (2003) vastly discusses the caring thinking model based on the western context, Mohd Daud Hamzah and Abdul Kadir Arifin's (2001) cognition model attempts to highlight human cognitive process from an Islamic perspective.
\end{abstract}


Significance - These findings suggest the need to understand the derivation of human cognition processes, that further explains the ability to sense bad and good values in moral virtue development. Fundamentally, this discussion considers the perspectives of both models regarding the formation of an individuals' thoughts and behaviours, which reflect the attributes of 'caring thinking'. It implies that greater effort should be undertaken to explore how caring thinking can be made useful to the field of education.

Keywords: Caring thinking, Islamic cognitive process, human cognition.

\section{INTRODUCTION}

Education is generally regarded as a means and an end to better well-being. In other words, education is not merely seen as a process that enables individuals to regurgitate acquired knowledge, but one that enables them to humanise themselves. In relation to that, the responses people have towards global development have caused various deteriorating impacts on the idea of injecting values in order to civilize humans (Rosnani Hashim, 2017). The existing practices in which education is usually valued in terms of physical grades and credits (Rosnani Hashim, 2009; Rosnani Hashim, Suhailah Hussien \& Adesile M. Imran, 2014) have also overlooked the importance of this affective aspect. Apart from instilling information, knowledge and critical thinking, it is believed that caring elements should be attached to contemporary education because they are crucially needed to reflect the internalisation of ethics and values (Rosnani Hashim, 2017).

As hubs that produce future leaders, institutions of learning are generally perceived as centres of excellence. For instance, the Ministry of Education, Malaysia (2017) is making efforts to develop an education environment that encourages the growth of premier knowledge centres as well as produce individuals who are competent and innovative with high moral values to meet national and international needs. In this regard, one vital question that arises is; 'Do students do well in their studies, and simultaneously possess and manifest good values?' 
Due to limited ethical or caring thinking elements in our pedagogy (Rosnani Hashim, 2017), it is actually possible to encounter a high achiever who does not care to stop bullying; and a creative artist who does not care about the negative effects of vandalising walls and school desks. There are several other anecdotal instances which are contradictory to the concept of caring. As noted by Lipman (2003) "to care is to focus on that which we respect, to appreciate its worth, to value its value" (p. 262). From the Islamic Psychology perspective, those examples reflect how one's morals are very much influenced by cognition processes (such as tafakkur and tadabbur) rooted from the clean qalb (heart) which direct rational thoughts and behaviours. These are consistent with the premise shown in the discussion about the relationship between orientation and behaviours, which posits that intrinsic construct that goes beyond the level of knowing antecedes behaviours (Mohamad Sahari et al., 1999).

Juujarvi, Myyry and Pesso $(2010,2012)$ also claim that care reasoning implies virtue enhancement. The Malaysian education setting is often considered as always emphasising cognitive development and vocationalism while little emphasis is given to character and spiritual growth (Rosnani Hashim, 2011). The norm has been that certain education stakeholders (such as teachers, parents and individual students) pay more attention to examination results. Thus, students who graduate from such a system may not have the requisite aptitude to critically, creatively and caringly make sense or meaning from what they have acquired (Rosnani Hashim, 2011).

In order to address the issue, the Ministry of Education in Malaysia has started to inject the elements of 'Higher Order Thinking Skills (KBAT)' in the curriculum, pedagogy and assessment. It is considered as a good effort with the intention of producing individuals with wisdom. Nevertheless, this endeavour requires much work because it has been greatly challenged by the culture of measuring excellence through grades (Irfan Naufal Umar \& Noor Hazita Ahmad, 2010; Rosnani Hashim, 2017). The imbalanced attention given by society and the teacher community (which may be reflected in the pedagogy practised by some teachers) may justify the limited ability of some adolescents to practice certain cognitive processes with values attached to them. The production of such individuals is extremely a necessary. However, one of the vital elements required in building a balanced and morally developed nation is a community that thinks caringly (Mohamad Sahari et al., 1999). 


\section{PROBLEM STATEMENT}

Muslim educationists have been promoting the elements associated with the concept of caring thinking in their agenda of producing wellbalanced and successful ummah (Rosnani Hashim, 2011). However, advancement in the world have witnessed a reduction in this exercise due to the spread of western civilization to Islamic countries, in which the society becomes money and material seekers. Every individual fights hard to gain monetary or material returns, thereby resulting in an individualistic society which 'does not care' anymore. The condition is interestingly addressed by Matthew Lipman (2003) who postulates the concept of caring thinking. Having observed identical nuances and some distinguishable elements underlying Lipman's (2003) thinking model and Islamic cognitive processes, the researchers selected Mohd Daud Hamzah and Abdul Kadir Arifin's (2001) model as a framework to conduct a comparative study. This is to adress the dearth of literature that highlights caring thinking, especially in light of an Islamic perspective, in comparison with the conventional western model (Rosnani Hashim, 2017).

\section{METHODOLOGY}

Literature related to Matthew Lipman's (2003) Thinking Model and Mohd Daud Hamzah and Abdul Kadir Arifin's (2001) Islamic Cognitive Processes Model (ICPM) were collected and reviewed. The review basically scrutinised these two texts:

1. Lipman, M. (2003). Thinking in education. Cambridge: Cambridge University Press.

2. Mohd Daud Hamzah \& Abdul Kadir Arifin. (2001). The deployment of Islamic cognitive processes by different groups of students during reading. Muslim Education Quarterly. 18(2). 35-60.

Lipman's (2003) text, 'Thinking in Education', was selected because his model of caring thinking has been globally accepted due to its impact on teaching and learning practices (Dombayci; 2014; Hannam \& Echeverria, 2009; Park \& Cho, 2016; Sharp, 2014). It is a continuation of his renowned Philosophy for Children (P4C) Programme which was partly developed to aid a thinking-based project for Jewish Education (Glaser \& Gregory, 2017). Using the Torah as the main text in the curriculum, the project aimed at 
promoting hermeneutical engagement within the education realm with the integration made with the western philosophical tradition.

In regard with the Islamic perspective, the work of Mohd Daud Hamzah and Abdul Kadir Arifin (2001) was chosen because it is a detailed and scientifically written article which discusses the Islamic cognitive processes that take place as learning progresses. It presents the theoretical expectation of an ideal learning process which clearly illustrates the role and the interplay of caring elements in the aspects of thought and emotion. Documented by Cambridge (Mohd Daud Hamzah \& Abdul Kadir Arifin, 2001), its content is believed to be comparable with Lipman's (2003) work since both focus their discussion on thinking and cognition.

The direction of teaching and learning from Lipman's (2003) view of caring thinking is to drive individuals towards developing their humanistic sense, which is similar to the model postulated by Mohd Daud Hamzah and Abdul Kadir Arifin (2001). It is the addition of a sense of godliness to stand beyond the humanistic purposes of teaching and learning propagated in the ICPM that intrigued the authors to conduct a comparative review between the two models. Even though Lipman's (2003) work concentrates on the idea of bringing religious values into individuals' everyday life practices (Glaser \& Gregory, 2017), elements of God-conscious thoughts in the conceptualisation of Caring Thinking have not been vividly stated within the afore-mentioned text under study. Nevertheless, it is believed that both models have the same weight such that teaching and learning should emphasise the idea of educating the mind and the heart. The reviewing process basically highlighted the comparable overview of thinking and cognition, in addition to identifying the elements of caring thinking concept towards forming an education of wisdom.

Through a cross-cultural comparative lens, the analysis attempted to comprehend the mechanisms which undergird the concept of Caring Thinking. As suggested by Rickinson and May (2009), it examined how the two philosophical schools of thought share certain similarities and unique differences. From the emic perspective (Brislin, 1976), the aspects of comparison include cognition principles, caring thinking inventory, thinking direction, human characterisation and 
role of beings. This comparative analysis allowed the researchers to gain greater insights into the theoretical and cultural suppositions underpinning certain concepts, and thus enabled us to better model the concept considering the existing contextual factors (Chin, 2017).

\section{FINDINGS AND DISCUSSION}

\section{Lipman's (2003) Multidimensional Thinking Model}

Well recognised for his propagation of the "Philosophy for Children" (P4C), Matthew Lipman (2003) has long been concerned about the skills of thinking and reasoning among individuals. He has devoted his life to teaching people the right way of thinking. Postulating the idea of bringing philosophy into the classroom in order to develop thinking skills, Lipman gathered his thinking about 'thinking' in a renowned book entitled "Thinking in Education". In this book, Lipman (2003) presents to the readers his transactive multidimensional thinking model which highlights the three types of thinking: Critical, Creative and Caring (the 3C's) (see figure 1).

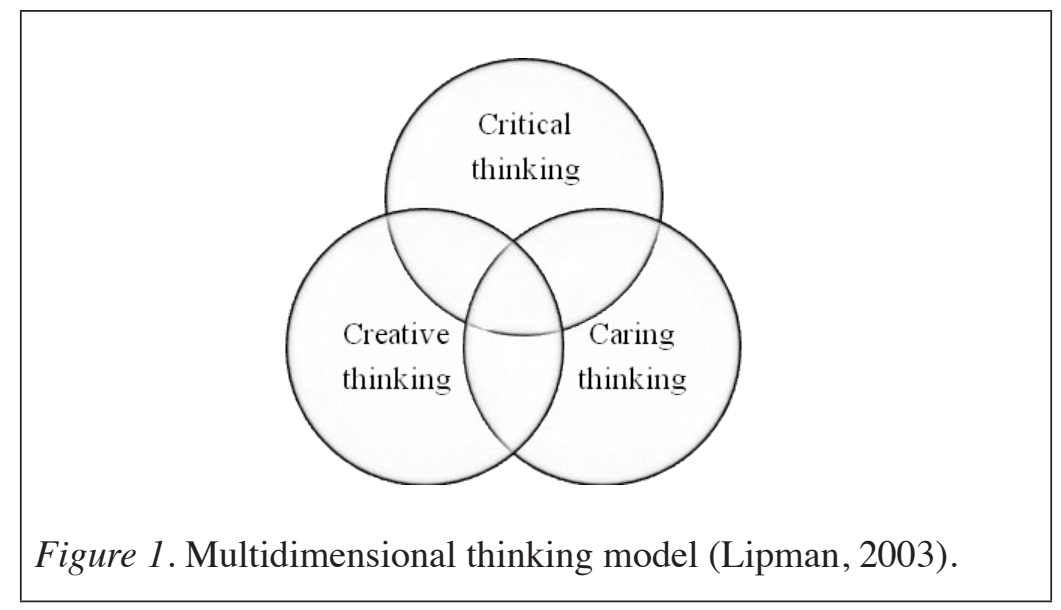

While education greaty values aspects of criticalness and creativity (Harkin, Turner \& Dawn, 2001; Lee, 2007; Norizan et al., 2010), inculcating care is also needed in complementing the aforementioned educational emphases. A focus on criticalness and creativity may result in individuals with high level of intellect and creativeness. 
However, the aim of producing holistic individuals would remain an aim as the softer elements of a person are detached from the pedagogy. Thus, these three thinking dimensions (Critical, Creative and Caring Thinkings) should be regarded equally by individuals within the educational circle, especially educators and learners. According to Lipman (2003),

For the schools to be committed to eliciting from each student an equilibrium among the critical, creative and caring aspects of thinking would result, it seems to me, in a dramatic change in the nature of education...A classroom would have to be a community of inquiry that facilitates creative and caring thinking. It could not be a factory for the production of solely intellectual operations, wholly indifferent to or actually hostile to the consideration, respect, and appreciation that the members of the class might have for each other or for the subject to be studied. (p.202)

Besides considering the 3C's as equally essential, Lipman (2003) suggests that multidimensional thinking should be seen in an integrated manner. Not regarding the $3 \mathrm{C}$ 's as different single entities, Lipman (2003) states that they are highly transactive and interdependent of one another. In other words,

In teaching for multidimensional thinking, one must be on one's guard not to give the impression to students that critical thinking is equal to the whole of thinking. Likewise, one should not give the impression that the three different modalities of thinking are independent rather than in continual transaction with each other (Lipman, 2003, p. 201).

Moreover, the basic idea of the 3C's in integration is to balance between the cognitive and the affective, between the perceptual and the conceptual, between the physical and the mental, as well as between the rule-governed and the non-rule-governed (Lipman, 2003, pp. 199-200). Human beings come into the world in a complete package comprising both the external physical body and its internal elements. While the internal elements consist of both cognitive and affective aspects, it is necessary to equally train such aspects so as to produce holistic individuals. In Lipman's (2003) words: 
It is my hope that we can thus achieve an education that enriches, enlightens, and liberates, that fosters understanding, strengthens judgment, improves reasoning, and imparts a clear sense of the relevance of inquiry to the enlargement of humanity (p. 6).

\section{Lipman's (2003) Caring Thinking Concept}

The concept of Caring Thinking was introduced by Matthew Lipman at the Sixth International Conference on Thinking in Boston in 1994 (Dombayci, Demir, Tarhan \& Bacanli, 2011). Being a part of higher order thinking, it is considered that caring thinking is rooted in the role of emotion in thinking. According to Lipman (2003),

We tend to identify critical thinking with reasoning and argumentation, with deduction and induction, with form, structure and composition. We fail to see how profoundly our emotions shape and direct our thoughts, provide them with a framework, with a sense of proportion, with a perspective, or better still, with a number of different perspectives. Without emotion, thinking would be flat and uninteresting (pp. 261262).

The desire to have a true education would not be achieved if thinking among the people are "uninteresting" and "flat". In fact, education without caring thinking seems to be against the nature of a human being, since an individual is composed of a combination of cognitive and affective elements. Dombayci et al. (2011) claim that cognitive and affective domains are inseparable. This proves that emphasis on caring thinking in one's education is escential.

Without offering any solid definition of caring thinking, Lipman (2003) explains the concept through an inventory of several caring thinking varieties such as appreciative thinking, affective thinking, active thinking, normative thinking and emphatic thinking. These five features of caring thinking are explained briefly in Figure 2. 


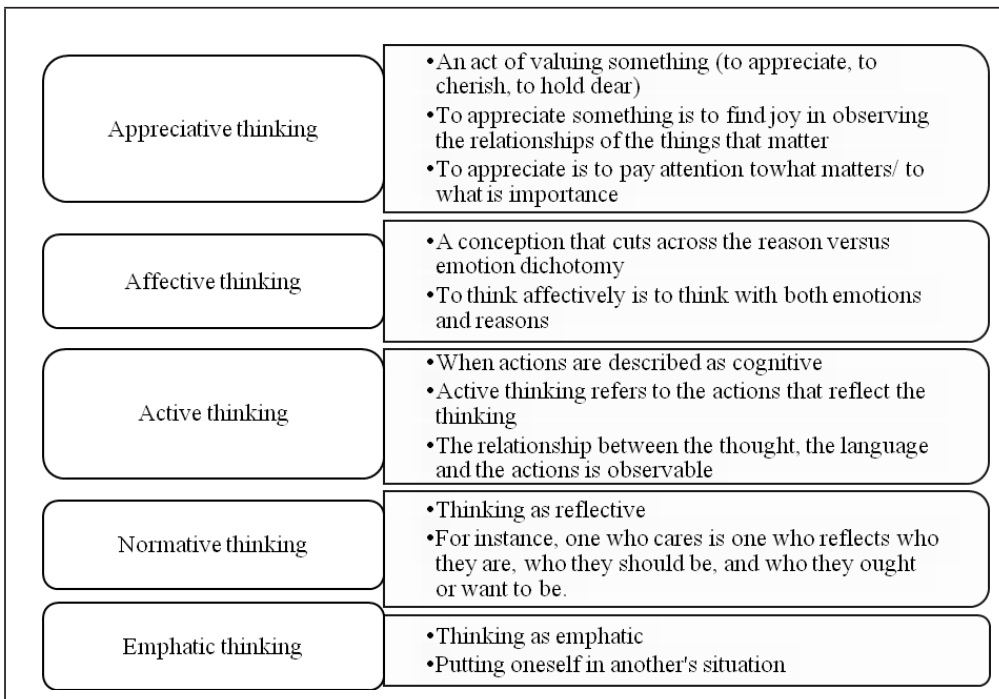

Figure 2. Caring Thinking Inventory (Lipman, 2003).

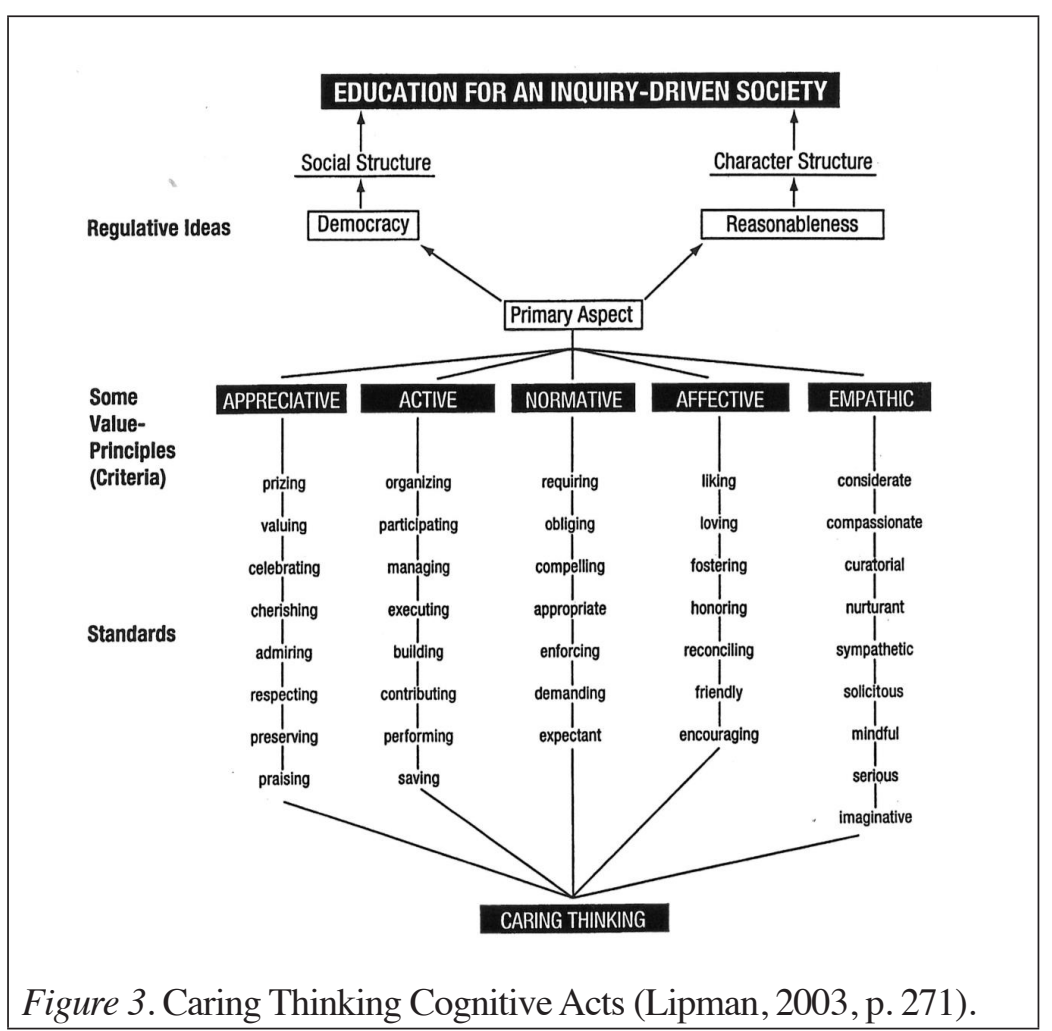


The five kinds of caring thinking offer thinkers a thought of being thoughtful in any context and circumstances. In summary, Lipman (2003) highlights two main answers to the question 'Why caring thinking in education?' First, caring possesses the quality to be part of the cognitive processes (with certain mental acts like filtering, gauging, screening and weighing) as indicated in Figure 3. The second reason is the idea of promoting values among individuals. Without the injection of the caring element into thinking, individuals would have the tendency to attend to matters indifferently and uncaringly.

\section{Mohd Daud Hamzah and Abdul Kadir Arifin's Islamic Cognitive Processes Model}

Having discussed caring thinking as part of the cognitive processes, it is fundamental to examine it from the perspective of Islamic cognition. Mohd Daud Hamzah and Abdul Kadir Arifin (2001) base their model of cognitive processes on four axes of energy namely an-nafs, al-qalb, al-ba'ithah and al-hawa. These axes operate interdependently to form the human cognition under structure (Mohd. Daud Hamzah \& Abdul Kadir Arifin, 2001) (Figure 4).

An-nafs is the axis of energy which constitutes the essence of mankind. It is best referred to as the 'self'. According to Al-Ghazali, there are seven states of an-nafs, in which each state indicates the quality of the self. These include an-nafs al-ammaarah (the irrational mind which generates irrationality and ignoble traits such as meanness, maliciousness, arrogance and indifference to Allah) as the lowest state. The state of the self may ascend through other states namely an-nafs al-lawwamah (when a man struggles against the temptations of ignobleness) and an-nafs al-mutmainnah (when a man is no longer disturbed by the irrational temptations and is ready to comply with Allah's decrees). Above these states are more superior states reflecting much better quality of the self - nafs mulhamah, nafs mardiyyah, nafs radiyah and nafs kaamilah. The process of the self ascension is called tazkiyatunnafs (purification of the self) which involves two sub-processes: Takhalli (eliminating the ignobleness) and tahalli (implantation of the noble characteristics). 


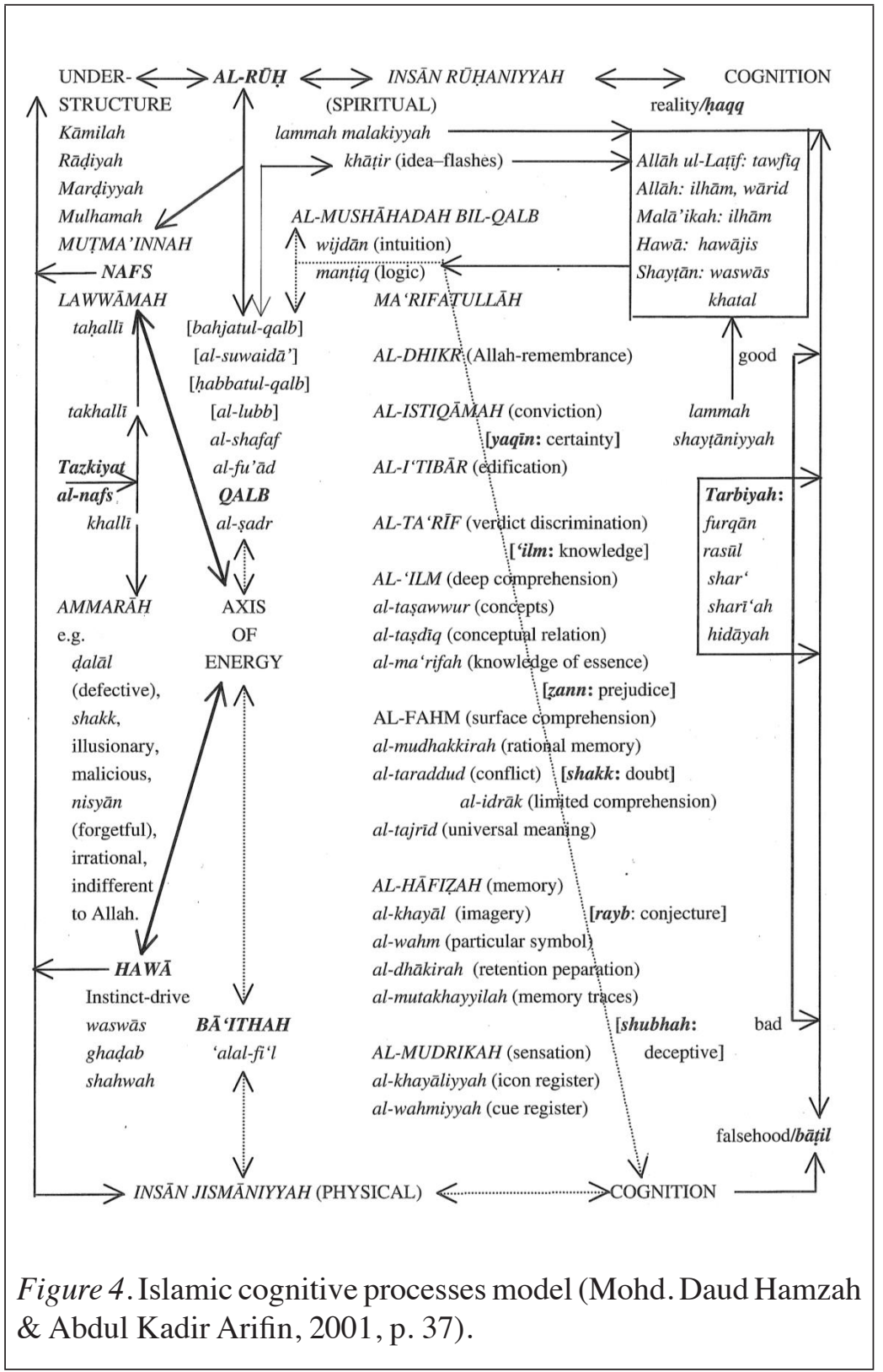

Al-qalb refers to the axis of energy that emanates rationality and forms the intellective mind. In other words, it is the seat of knowledge. It is reflected in unison of the heart and the brain. To Al-Ghazali, alqalb contains intellect or ' $a q l$ - the generator of thinking or ideas. 
Aql in human beings is the one that differentiates us from animals. With $a q l$, a man is capable of reading, observing, translating and comprehending the signs of Allah. Forming the intellective brain and heart, $a l$-qalb forms the rational essence of a man which enables him or her to make decisions and choices in life. Thus, al-qalb plays a role to activate a man's patterns of conduct and hence, determine the state of the nafs.

It is claimed that both al-qalb and an-nafs strongly influence an individual's cognitive activities. Now the question is 'how does man manifest his or her self?' This leads us to discuss al-baa'ithah. Albaa'ithah is the axis of energy containing the physical force. It is a form of energy which actualizes the potential of an-nafs. According to Al-Ghazali, the physical body is the attire of the nafs. Hence, albaa'ithah acts as the arousal power source for sensation of cognitive inputs.

Serving as a modifying effect to human cognition, apart from albaa'ithah, al-hawaa is another axis of energy which is necessary to discuss. It is one of the main concepts which has the automatic 'tuning' energy for cognitive activities. Al-hawa depicts the energy that attunes one toward ignobleness and enjoyment of the world while forgetting Allah. In other words, it transmits the lowest state of 'aql and qalb, and further reflects the direction of the self towards an-nafs al-ammaarah. This leads to bad thinking, bad feelings and bad behaviour. This illustrates how al-hawaa is so powerful in tuning the nafs, the qalb and the baa'ithah. Therefore, the presence of al-hawaa in cognition actually drives a person to adequately balance himself or herself. It reinforces the need for proper cognitive development among individuals, especially in freeing the energies from the distraction of the hawaa.

\section{Cognition Principles from the Perspective of Islam}

Based on the four axes of energy discussed above, Mohd Daud Hamzah and Abdul Kadir Arifin (2001) trace four principles of cognition:

Al-mudrikah (sensation) - al-mushaahadah bi 'l-qalb(inner witness): Beginning with the inputs gained through the senses (al-mudrikah), 
different forms of cognition ascend through memory (al-haafizah), superficial comprehension (al-fahm), deep comprehension (al-' $\mathrm{ilm}$ ), discriminatory verdict or the ability to produce correct judgment (at-ta'rif), edification - in search of wisdom closure to an event (alI'tibaar), conviction (al-istiqamah), Allah-remembrance thinking (al-dhikr), discernment of Allah (ma'rifatullah), and inner witness (al-mushaahadah bi 'l-qalb).

Mantiq (logic) - wijdan (intuition): The form of sensation is a process based on logic and the inner witness or mushaahadah is totally an intuitive process. Other cognitive forms are believed to have various combinations of logic and intuition.

Lammah malakiyyah (divinity) - lammah syaytaaniyyah (devilishness): These two extremes explain how one's mental ideas may be directed of the divine sources or could also originate from the direction of the devil.

Shubhah (deception) - yaqin (certainty): The stages of mental process ascend through those which are deceptive (shubhah), imaginative $(r a y b)$, doubtful (shakk), prejudicial (zann), to knowledgeable (' $i l m)$ and finally certainty (yaqin).

\section{The Place of Caring Thinking in the Islamic Cognitive Processes Model}

This section revisits the reasons underlying Lipman's (2003) postulation of the caring thinking concept. Besides highlighting the importance of value instillation into learners of caring is seen as an element which contains certain cognitive acts. It is considered as part of higher order thinking since it involves mental processes such as filtering, gauging, screening and weighing. From the Islamic viewpoint, a person is to pass through five initial stages of cognitive processes - sensation (al-mudrikah); memory (al-haafizah); superficial comprehension (al-fahm); deep comprehension ( $\mathrm{al}$-' $\mathrm{ilm}$ ); and discriminatory verdict (at-ta'rif) - in making a proper judgment that is free from any prejudice. The ability to deeply comprehend a matter and make discriminatory verdict between the bad, the good and the best necessitates the possession of caring thinking. Why is this so? Lipman (2003) claims that caring thinking is a dimension 
of thinking which is against selfishness and individualism. In order for one to care for or about certain matters, one must be free from selfishness and to be free from selfishness is to be able to deploy at-ta'rif. A person may be considered as selfish when he or she is not able to make correct judgment, for it may contain biasness and individual preferences. In fact, caring in Islam could even be a higher form of cognitive act, in which a person does something as he or she cares about what God thinks of him or her. One cares when one is able to find the wisdom behind certain matters, and with remembrance of Allah within oneself, caring thinking is an automatic mental act.

The possession of certain cognitive acts such as comprehension and decision-making indicate that caring thinking lies within the two edges - Mantiq (logic) - wijdan (intuition). For a person to think caringly, it requires both logics and intuitions. However, there are times when certain situations may seem illogical and beyond what can be seen. Thus, intuition plays a role in this moment. In other words, caring does not only require the mind to work, but also the heart, which releases the sense of good intuition. When the mind and heart; or logic and intuition combine, the behaviours that manifest those cognitive processes are a reflection of the caring thinking.

In Islam, caring thinking is one's mental ideas which is directed by divine sources (lammah malakiyyah). It is against the direction of lammah syaytaaniyyah (devilishness). Obviously, caring is a matter of positivity and it is directed to and from divinity. Lipman's (2003) inventory of caring thinking, i.e., appreciative, affective, active, normative and emphatic, portrays the instilment of malakiyyah values within an individual. This explains why Islam emphasises the process of tazkiyah an-nafs (self-purification) - in which the process seeks to eradicate the bad (hawaa) and instill the good.

Within this process, an individual's cognition undergoes a few stages between Shubhah (deception) and yaqin (certainty). Values instillation requires every single learner to learn and to have knowledge (' $i l m$ ). With knowledge, and later with certainty (yaqin), one is believed to possibly have the ability to think caringly. As noted by Lipman (2003), caring thinking is a mode of appreciating matters. It is almost impossible for someone to have an appreciative manner 
if his/her thinking is somewhat deceptive (shubhah), imaginative $(r a y b)$, doubtful (shakk), and prejudicial (zann). In summary, it could be seen that caring thinking has a higher place within the range of cognition principles (Mohd. Daud Hamzah \& Abdul Kadir Arifin, 2001).

\section{A Review of Caring Thinking in Both Models}

As stated in the problem statement, Muslim educationists have been propagating the instillation of value-based thinking (Rosnani Hashim, $2003,2011)$. This value-based thinking is interestingly paralled with Lipman's (2003) concept of caring thinking. In their formulation of the ICPM, Mohd. Daud Hamzah and Abdul Kadir Arifin (2001) refer to the works of Al-Ghazali. Among the segments they quoted is the explanation of the 10 maqamat (states) an individual has to experience within the process of tazkiyah an-nafs (self-purification). These 10 states of a being are seen as reflective of the five types of thinking encapsulated in the caring thinking concept.

Appreciative thinking resembles the state of syukr (thankfulness) while affective thinking - which speaks about the emotions and the ability to control temper - is reflected in the states of mahabbah (love) and sabr (patience). As for active thinking, one's decision concerns the implications of the actions one decides to take, and this is best described by the terms of raja' (hope) and khawf (fear). Both hope and fear become the motivation for a person to reason each decision he or she makes in life. Besides, Islam also promotes normative thinking as it always encourages reflections and tawbah (repentance) among its ummah. Reflection only without repentance is seen as inadequate, for reflections must be followed by the efforts of self-betterment. Finally, caring in its form of emphatic thinking could be reflected in the state of faqr (poor). An individual has to realize how poor he or she is as everything in this world is God's. Therefore, thinking that we are faqr is a humbling process which allows us to have emphatic thinking. In other words, thinking faqr enables people to experience what others are experiencing, thus making them a caring society. Figure 5 illustrates the connection between the sub-concepts postulated by Lipman (2003) and the Islamic view of those sub-concepts. 


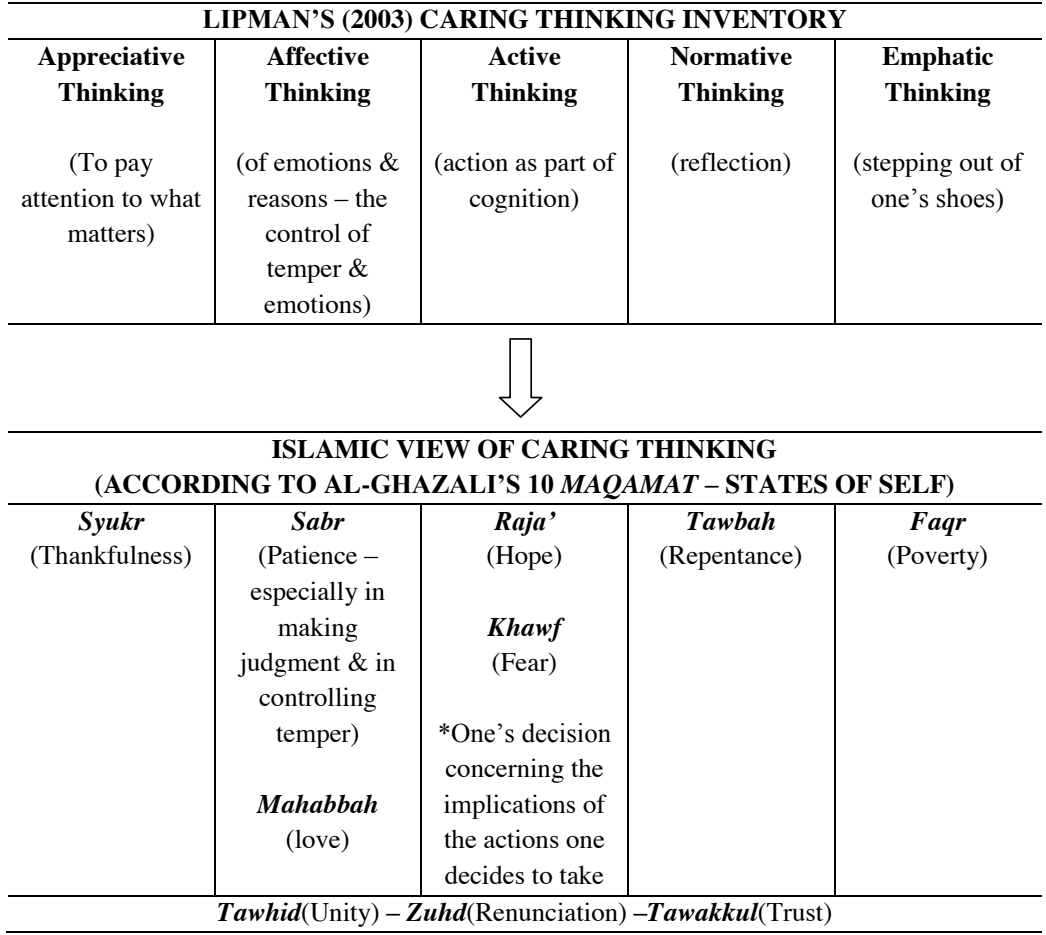

Figure 5. Comparison between Lipman's inventory of caring thinking and the Islamic view (Lipman, 2003; Mohd. Daud Hamzah \& Abdul Kadir Arifin, 2001).

Having compared the concept from both cultural perspectives, it is interesting to note that at least there are three sub-concepts explained by Al-Ghazali which do not seem to reflect the western's view of caring thinking. They are the tawhid (unity or oneness of God), zuhd (renunciation or the rejection of invalid matters) and tawakkul (trust one puts in God). These three sub-concepts speak about the belief or faith of an individual towards Allah which influences his or her thinking. According to Islamic perspective, these three elements govern all the other elements explained earlier. This is an indication that every state of self should begin from Allah and end with Allah. In other words, the Muslim psychologists view that Allah is the ultimate source of thinking and the ultimate reason of thinking (Aisha Utz, 2011).

To review both models, besides having a glimpse of the cognition principles and the caring thinking inventory, the discussion is now 
focus on the philosophical bases comprising several aspects of comparisons namely thinking direction, human characterisation and role of beings.

Thinking direction in Lipman's (2003) thinking model focuses only on the development of 'human for human'. This is obvious since Lipman (2003) did not include the element of faith in his concept of caring thinking. Unlike the idea proposed in Mohd Daud Hamzah and Abdul Kadir Arifin's (2001) cognitive model, the thinking direction requires a larger scale of discourse. It covers not only the current world but also the life hereafter as Muslims are taught to have not only worldly intentions yet a rather higher and farther morality underlying their thinking and the actions - which is to obtain the blessings of God.

In terms of comparison of the aspect of human characterisation in caring thinking, Lipman (2003) emphasises both mental health and emotional stability as preparations to function according to the norm permissible to a certain context or community. In other words, the human character seems to be very physical in nature. On the other hand, human character, from the Islamic perspective is rather holistic. Caring thinking in Islam covers both the external and internal aspects of self-transformation and betterment. The internal aspect here refers to the intention of achieving ma'rifatullah as the purpose of life. This leads human beings to experience not only temporary inner peace but also an eternal one.

In terms of the role of individuals in manifesting caring thinking, Lipman (2003) divided human roles as the entity of a being and a community contributor. In contrast, Mohd Daud Hamzah and Abdul Kadir Arifin (2001) view human as an entity comprising the identities of an individual and a social counterpart, besides a servant to God. Caring in Islam is believed to be in both directions vertically (relationship between oneself and Allah) and horizontally (relationship between oneself and other beings). In other words, Islam expects a human being to fulfill the rights of both relationships in a balanced manner. Quality of life in Islam is perceived through one's accomplishment in balancing one's vertical and horizontal relationships (hablumminallah and hablumminannaas).

In a nutshell, it could be said that there exist several nuances in both models which are similar to one another, particularly in terms of the 
values promoted in caring thinking. Nevertheless, a few elements seem to be missing in the Western context - those which connect thinking with Ihsan (a state in which the person is aware that Allah is witnessing) as emphasised within the culture of the Muslim community.

\section{CONCLUSIONS AND IMPLICATIONS}

Lipman's (2003) work on the concept of caring thinking represents a good effort in promoting values within people's thinking frame. The concept prompted the authors to reflect on the similarities in the intention of such ideas with those promoted in the Islamic setting. While the discussion of Lipman (2003) on caring thinking is highly valued, Mohd Daud Hamzah and Abdul Kadir Arifin's (2001) work is appreciated as the ICPM can explain caring thinking from the Islamic perspective. Islam encompasses all human life dimensions and is a reflection of a person's the multidimensional experiences - not only as a khalifah (leader) on this earth but also as a servant to God. The main concern of this experience is the purification of one's life journey in this world which is headed towards the life hereafter.

Having argued from an educationist point of view, it becomes necessary to bring the discussion to pedagogical implications. How can caring thinking be made useful? Caring thinking offers various values to be learnt, practiced and experienced (Dombayci; 2014; Hannam \& Echeverria, 2009; Juujarvi, Myyry \& Pesso, 2012; Park $\&$ Cho, 2016; Sharp, 2014). It is believed to promote individual and collective growth among learners holistically, comprising cognitive, affective and psychomotor development. Briefly, the process of injecting values could be made possible by using caring thinking.

Of such efforts, the biggest challenge is about articulating appropriate and nurturing pedagogical approaches to embrace the mind, heart and action in educating humans. The understanding of the details and specific interplay of caring and thinking enable us to make the true education explicit. With this encouragement, we believe that the education community should be exposed to the value of thinking (Rosnani Hashim, 2003,2014) and the thinking of values (Mohamad Sahari, 1999). 
Since caring thinking is still new to certain education systems such as Malaysia (Abdul Shakour Preece \& Adila Juperi, 2014), its importance is apparent. For the purpose of producing education graduates who are competent physically, intellectually, emotionally and spiritually, the National Philosophy of Education should be practised. In order to enable learners to think caringly, the educators must first be equipped with both the knowledge and the practice of caring thinking (Folsom, 2005). Embracing to the philosophy of education wholeheartedly is an initial way of exercising caring thinking.

Due to lack of exposure among educators in Malaysia to caring thinking (Abdul Shakour Preece \& Adila Juperi, 2014), the Centre for Philosophical Inquiry in Education as well as the International Islamic University Malaysia introduced "Hikmah Pedagogy" in 2006. Besides serving the goals of enhancing critical thinking skills and improving creativity, personal and interpersonal growth, the pedagogy is also designed to aid educators in delivering their lessons in a caring manner. This is in addition to instilling the concept of caring thinking among learners (Rosnani Hashim, 2009, 2011, 2017). Because of its reported success, it is recommended that education stakeholders should be exposed to such pedagogical practice with the intention of reviving a lost intellectual culture in our current educational realm.

The discussion in this paper, suggests that the implementation of caring thinking within the education of a Muslim majority nation would possibly be fruitful when both models are taken into account. This cross-cultural review on caring thinking has shed some light on how educators could benefit from the internalization of caring thinking, particularly its suitable deployment. In order to realize true education, muslim educators have attempted to build critical and creative individuals - but now who should care about producing caring thinkers?

\section{ACKNOWLEDGEMENT}

This work was funded by Universiti Sains Malaysia under the USM Global Fellowship Scheme. 


\section{REFERENCES}

Abdul Shakour Preece \& Adila Juperi. (2014). Philosophical inquiry in the Malaysian educational system - reality or fantasy? Analytic Teaching and Philosophical Praxis, 35(1), 26-38.

Aisha Utz. (2011). Psychology from the Islamic Perspective. Riyadh: International Islamic Publishing House.

Brislin, R.W. (1976). Comparative research methodology: Crosscultural studies. International Journal of Psychology, 11(3), 215-229.

Chin, L. G. (2017). Comparative analysis in group processes: Expanding the reach of sociological social psychology. International Journal of Sociology, 47(4), 251-258.

Dombayci, M.A., Demir, M., Tarhan, S. \& Bacanli, H. (2011). Quadruple thinking: Caring thinking. Procedia Social and Behavioural Sciences. Elsevier.

Dombayci, M.A. (2014). Teaching of environmental ethics: CaringThinking. Journal of Environmental Protection and Ecology, 15(3A), 1404-1421.

Folsom, C. (2005). Exploring a new pedagogy: Teaching for intellectual and emotional learning (TIEL). Issues in Teacher Education, 14(2), 75-94.

Glaser, J. \& Gregory, M.R. (2017). Education, identity construction and cultural renewal: The case of philosophical inquiry with Jewish Bible. In Gregory, M. R., Haynes, J. \& Murris, K. (Eds). The Routledge international handbook of philosophy for children. (pp. 180-188). London: Taylor \& Francis.

Hannam, P. \& Echeverria, E. (2009). Philosophy with teenagers: Nurturing a moral imagination for the 21st century. London: Network Continuum.

Harkin, J., Turner, G., \& Dawn, T. (2001). Teaching young adults: A Handbook for teachers in post-compulsory education. London: Routledge Falmer.

Irfan Naufal Umar \& Noor Hazita Ahmad. (2010). Trainee teachers' critical thinking in an online discussion forum: A content analysis. Malaysian Journal of Learning and Instruction, 7591.

Juujarvi, S., Myyry, L. \& Pesso, K. (2010). Does care reasoning make a difference? Relations between care, justice and dispositional empathy. Journal of Moral Education, 39 (4), 469-489.

Juujarvi, S., Myyry, L. \& Pesso, K. (2012). Empathy and values as predictors of care development. Scandinavian Journal of Psychology, 53, 413-420. 
Lee Lik Meng. (2007). The construction of a constructivist: Learning how to teach without teaching. Pulau Pinang: Penerbit USM.

Lipman, M. (2003). Thinking in education. Cambridge: Cambridge University Press.

Ministry of Education, Malaysia. (2017). Official Portal of Ministry of Education, Malaysia. Retrieved on 20 October 2017 from http://www.moe.gov.my/?id=37\&lang=en

Mohamad Sahari, Abdul Aziz Mohd Sultan,Mohd Tahrim Raffor, Ismail Sheikh Ahmad, Ahmad Marzuki Zainuddin, Zainurin Abdul Rahman, Tunku Badariah Tunku Ahmad \& Haniza Rais. (1999). Inculcation of values across the school curriculum: Development and validation of teachers' orientation scale. Intellectual Discourse, 7(2), 155-168.

Mohd Daud Hamzah \& Abdul Kadir Arifin. (2001). The deployment of Islamic cognitive processes by different groups of students during reading. Muslim Education Quarterly, 18(2), 35-60.

Norizan Md. Nor, Noriah Mohamad, Hasuria Che Omar \& Ruslan Rainis (2010). The direction and future of higher education in Malaysia. In Zailan Moris (Ed.), 50 Years of Higher Education Development in Malaysia (1957-2007) (pp. 148-176). Pulau Pinang: Penerbit Universiti Sains Malaysia.

Park, E. \& Cho, A. (2016). Development and validation of youth's caring thinking scale based on Lipman's theory. Youth Culture Forum, 46, 114-132.

Rickinson, M. \& May, H. (2009). A comparative study of methodological approaches to reviewing literature. York: The Higher Education Academy.

Rosnani Hashim. (2003). Malaysian teachers' attitudes, competency and practices in the teaching of thinking. Intellectual Discourse, 11(1), 27-50.

Rosnani Hashim. (2009). Philosophy in the Islamic Tradition: implications for the philosophy for children (P4C) program. In E. Marsal, T. Dobashi, \& B., Weber (Eds.), Children philosophize worldwide: theoretical and practical concepts (pp.655-662). New York: Peter Lang.

Rosnani Hashim. (2011). Reviving the pedagogy of philosophical inquiry in Muslim curriculum for effective civilizational dialogue. In Macer, D. R. J. (Ed.), Asian-Arab philosophical dialogues on culture of peace and human dignity (pp. 138148). Bangkok: UNESCO.

Rosnani Hashim, Suhailah Hussien \& Adesile M. Imran. (2014). Hikmah (wisdom) pedagogy and students' thinking and reasoning abilities. Intellectual Discourse, 22(2), 119-138. 
Rosnani Hashim. (2017). P4C in the context of Muslim education. In Saeed Naji \& Rosnani Hashim. (Eds.), History, theory and practice of philosophy for children: International Perspective (pp. 170-179). London: Routledge.

Sharp, A.M. (2014). The other dimension of caring thinking. Journal of Philosophy in Schools, 1(1), 16-21. 